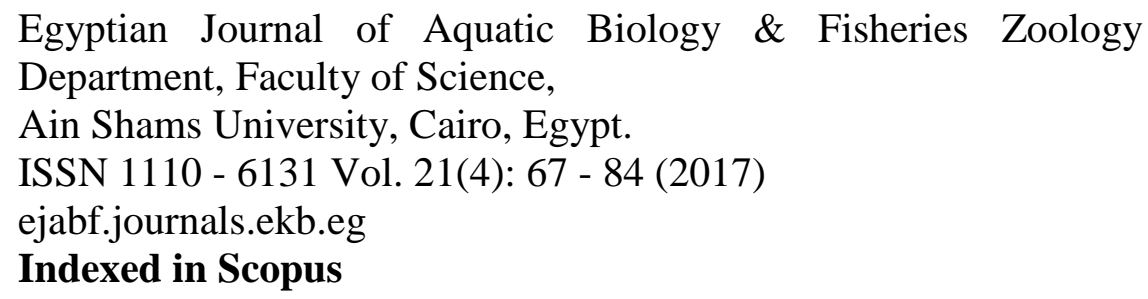

\title{
Studies on Some Heavy Metals and Bacterial Pollutants in Tilapia Fish of El Salam Canal, Northern Sinai, Egypt.
}

\author{
Gehad R. Donia ; Amani A. Hafez and Islam M. Wassif \\ Department of Animal and Poultry Health, Animal and Poultry Production Division, Desert \\ Research Center, Cairo, Egypt. \\ Corresponding author: gehad.donia@yahoo.com
}

\section{ARTICLE INFO}

Article History:

Received: Dec. 30, 2017

Accepted: Jan. 28, 2018

Available online: March. 2018

\section{Keywords:}

Heavy metals

Bacterial contamination

Tilapia fish

El-Salam Canal

Egypt

\begin{abstract}
The present study was conducted to investigate the distribution of bacteria and selected heavy metals (Al, Fe, $\mathrm{Zn}, \mathrm{Mn}, \mathrm{Cu}, \mathrm{Cd}, \mathrm{Pb}, \mathrm{Co}, \mathrm{Ni}$ and $\mathrm{Cr}$ ) in water samples and in the gills and muscles of the Nile tilapia (Oreochromis niloticus) grown along El- Salam Canal zone. Samples were analyzed by inductively coupled plasma-optical emission spectrometry (ICP-OES). The concentrations of heavy metals in water samples showed the high levels of heavy metals in the studying area. The levels of heavy metals in the fish samples can be considered as a serious matter of concern as it may be consumed and it signifies the degradation of canal quality. Regarding to microbiological analysis, the results showed an increase in some bacterial pollutants which linked with human disease. The counts of pathogenic bacteria Pseudomonas aeruginosa ranged from 80 to 200 MPN/100 ml, while that of Salmonella- Shigella varied from 0 to 30 CFUml and E.coli colony number range from 0 to 10 . In addition, the fish caught from the study area revealed the presence of different bacterial species. A total of eight bacterial species were isolated from fish and identified biochemically as Salmonella spp., Enterobacter cloacae, Rhizobium radiobacte., Fluorescens spp., Listeria monocytogenes, Streptococcus agalactiae, Streptococcus iniae and Aeromonas hydrophila. The bacterial count from each sample revealed $44.5 \times 10^{7} \mathrm{cfug}^{-1}$ from the gills, $20 \times 10^{8} \mathrm{cf} \mathrm{ug}^{-1}$ from the intestine and $38.75 \times 10^{8} \mathrm{cfug}^{-1}$ from the skin. The isolates were found to be of medical importance, so restricted measurements should be taken to inhibit the spreading of pollutant sources in El-Salam Canal.
\end{abstract}

\section{INTRODUCTION}

Fish is an important source of food for people and provide us for about $60 \%$ of the world's supply of protein, $60 \%$ of the developing countries received $30 \%$ of their annual protein from fish (Abisoye et al., 2011). It is one of the cheapest sources of protein in Africa (Claucas et al., 1996). The advantage of fish as its easy digestibility, and it has high nutritional value. Nile tilapia (Oreochromis niloticus) is the most important aquatic species produced and consumed in Egypt. It is a teleost fish with a worldwide distribution; therefore it is a good model for assessing the impacts of different environmental pollutants on aquatic ecosystems (Akan et al., 2009). 
Heavy metal residues and its hazard effects on the health of people are a matter of great concern to food hygienists.

They accumulated in fish not only have a bad influence on fish but they also affect the health of human beings through the food chain (Desta et al., 2012). Bioaccumulation of trace elements in living organisms and bio-magnification in them describes the processes and pathways of these possible pollutants from one trophic level to another, exhibiting the higher bioaccumulation ability in the organisms concerned. Increasing concentration through the food chain caused higher retention time of toxic substances than that of the other normal food components. Therefore, various fish species are widely used as bio-indicators of metal contamination (Svobodova et al., 2004). Under acidic conditions the free divalent ions of many metals may be absorbed by fish gills directly from the water. Hence, concentrations of heavy metals in organs of fish determined primarily the level of pollution in the water and food (Farkas at al., 2000). The concentration of pollutants in water samples only indicate the situation at the time of sampling, while concentrations in the organism are the result of past as well as current pollution levels in the environment in which the organism lives (Ravera et al., 2003). Water that resides in rivers, streams and lakes are major sources of drinking water. Thus, the pollution of these natural waters is one of the most critical environmental issues today. Inorganic compounds from natural and anthropogenic sources continuously enter the aquatic ecosystem where they pose a serious threat because of their toxicity, long time persistence, bioaccumulation, and bio magnifications in the food chain. Many groups of organisms can be used as a bioindicators of environmental and ecological change, but numerous publications attest that fish (in situ) are a good indicator of aquatic environmental change and ecosystem health, especially in the case of toxic water pollution (El-Shafei, 2015)). In aquatic ecosystems, heavy metals have received considerable attention due to their toxicity, accumulation in biota and biomagnification in the food chain (Emara et al., 2015). For the normal metabolism of the fish, the essential metals must be taken up from water, food or sediment. These essential metals as $\mathrm{Cu}, \mathrm{Fe}, \mathrm{Mn}, \mathrm{Zn}$ can also produce toxic effects when the metal intake is excessively elevated (Canli and Atli, 2003). The concentration of heavy metals in fish as a good indicator of aquatic environmental has been recommended by several researchers (Abdel-Mohsein and Mahmoud, 2015, Bayomy et al., 2015 and El-Shafei., 2015). Because health safety is very an important aspect of food quality, so the present study was carried out to investigate the rate of infection of tilapia with bacteria, as well as the extent of its presence in the water of the Nile. Also to estimate bioaccumulation of heavy metals and to produce baseline data on the distribution of heavy metals (AL, Fe, $\mathrm{Mn}, \mathrm{Cu}, \mathrm{Zn}, \mathrm{Ni}, \mathrm{Pb}, \mathrm{Cd}, \mathrm{Cr}, \mathrm{Co}$ ) in water and edible parts of commonly consumed fish species (Oreochromis niloticus) obtained from El-Salam Canal, Egypt. Analyses of these heavy metals in water and fish samples were used to evaluate the magnitude, impacts and possible sources of heavy metals contamination on the canal. Consequently tilapia is susceptible to a wide variety of bacterial pollutant, most of them causing disease and is considered by some researches to be saprophytic in nature (Lipp and Rose, 1997). The pathogenic organisms that cause mortality in tilapia are bacteria such as Aeromonas spp., Flavobacterium columnare., Francisella spp., Streptococcus agalactiae., Escherichia coli, Clostridium botulinum, Shigelladynteriae, Staphylococcus aureus, Listeria monocytogens and Salmonella. Some of these pathogens are distributed in warm water, such as River Nile, The disease is related to the interaction between fish, pathogens and their waterways (Snieszko, 1975 ; Lipp and Rose, 1997). When a fish is exposed to a bacterial 
pathogen in an unfavorable environment (as poor water quality or excess of organic matter) disease percentage is higher because the balance between the pathogen, host and aquatic environment destabilizes. However, fish contain a high bacterial diversity which results from a symbiotic effect among bacteria and tolerance by fish that protect them when adapting to nutritional changes and present of food in the digestive tract (Huong et al., 2014). Regarding to the microbiological diversity of the fresh fish muscle depends on the fishing grounds and environmental factors around it. The bacteria in fish only become pathogens when fish are physiologically unbalanced nutritionally deficient, or there are other stresses (Cahill, 1990). Therefore, it is important to identify the extent of heavy metal and bacterial content in fish samples by monitoring them to explain potential impacts on the food chain and human health risks.

\section{MATERIALS AND METHODS}

Study Area: the total length of El-Salam Canal is $242 \mathrm{~km}$, updated performed parts include $87 \mathrm{~km}$ West Suez Canal and $35 \mathrm{~km}$ East Suez Canal. The East Canal is known as El-Sheikh Gaber Canal on which different sampling locations were selected to cover the implement study area.

Laboratory Analysis: water and Tilapia fish (Oreochromis niloticus) samples were collected during one year [2015-2016]. The selection of sites was chosen to represent El-Salam Canal area as shown in Figure (1).

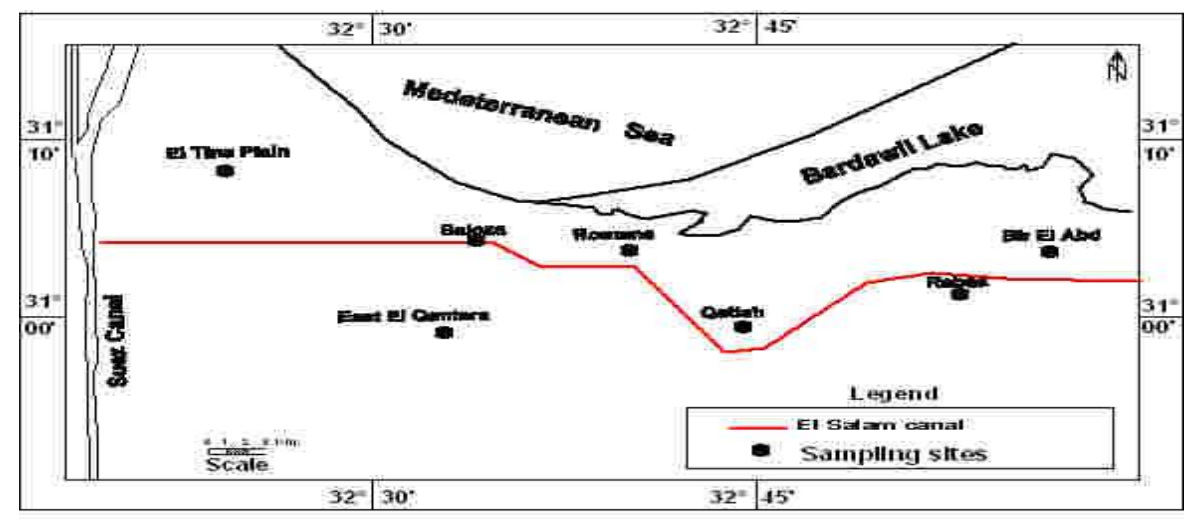

Fig. 1: Schematic Diagram for study area.

\section{Water samples}

For heavy metals analysis: about $100 \mathrm{ml}$ of each water sample were filtered through nitrocellulose filter membrane of $0.45 \mu \mathrm{m}$ pore size prior dried in $105^{\circ} \mathrm{C}$ for 2 hours. The filtrate and unfiltered water samples were preserved in $2 \mathrm{ml}$ concentrated nitric acid $\left(\mathrm{HNO}_{3}\right)$ to prevent precipitation of metals and growth of algae. Samples were collected according to international standard methods for examination of water and wastewater (APHA, 2005) to evaluate the concentrations of selected heavy metals. Samples were collected in stopper polyethylene plastic bottles, stored in an iced cooler box and delivered immediately to the laboratory for analyses. The plastic bottles were cleaned by soaking in $10 \% \mathrm{HNO}_{3}$ and the procedural blanks of standard solutions were prepared under clean laboratory environment.

For bacteriological analysis: about ten $\mathrm{ml}$ of each water sample was subjected to serially dilutions $\left(10^{-1}\right.$ to $\left.10^{-5}\right)$ with sterile physiological saline $(0.85 \% \mathrm{wt} / \mathrm{vol}$. $\mathrm{NaCl})$ in deionized water. The pour plate technique on nutrient agar medium was used for 
the enumeration of total bacterial counts at both $22^{\circ} \mathrm{C}$ and $37^{\circ} \mathrm{C}$ incubation temperatures. For total spore-forming bacteria, water samples and its serial dilutions were pasteurized for $15 \mathrm{~min}$ at $80^{\circ} \mathrm{C}$, prior to plating in nutrient medium and incubating at $30^{\circ} \mathrm{C}$. MPN technique was used for enumerated total and faecal coliforms (using MacConky broth medium) and faecal streptococci (using Azidedextrose broth medium), then incubated at $37^{\circ} \mathrm{C}$ for $24-48 \mathrm{~h}$.Eosin Methylene Blue (EMB) was used for enumerated Escherichiacoli and Violet Red Bile agar (VRB) for enumerated Enterobacterease. Asparagine broth medium was used for enumerated Pseudomonas aeruginosa as well as Salmonella Shigella agar (SS agar) was used for enumerated Salmonella spp. and Shigella spp. (APHA, 2005).

\section{Fish Samples}

For heavy metals analysis: fish samples were collected from different sites along ElSalam Canal area, they were washed with de-ionized distilled water to remove slime and/or ice, drained and water removed with tissue paper. Pieces from gills and muscles were taken and kept frozen at $-20^{\circ} \mathrm{C}$ then transported to laboratory for digestion and heavy metals analysis.

Samples Digestion: samples were prepared by mixing $0.5 \mathrm{~g}$ of wet weight fish tissues (gills and muscles) for 24 hours at $70{ }^{\circ} \mathrm{C}$ with $6 \mathrm{ml}$ concentrated $65 \% \mathrm{HNO}_{3}$ and $1 \mathrm{ml} 30 \%$ hydrogen peroxide $\left(\mathrm{H}_{2} \mathrm{O}_{2}\right)$ for digestion, using microwave digestion system (model Milestone, MLS-1200 mega, Germany) then ventilated for 5 min and filtrated to $100 \mathrm{ml}$ by using deionized water.

Analytical Procedures: laboratory analysis, all reagents were used for analytical grade and deionized water was used for all the prepared reagent solutions. Heavy metals ( $\mathrm{Al}, \mathrm{Fe}, \mathrm{Zn}, \mathrm{Mn}, \mathrm{Cu}, \mathrm{Cd}, \mathrm{Pb}, \mathrm{Co}, \mathrm{Ni}$ and $\mathrm{Cr}$ ), the samples were filtered by filtration system through membrane filter of pore size $0.45 \mu$ and were measured by inductively coupled plasma-optical emission spectrometry (ICP-OES) and their recovery studies for the trace elements ranged between 99 and $102 \%$.

For bacteriological analysis: one hundred and twenty tilapia fish were freshly captured (b.w. $350 \mathrm{gm}$ ), collected and examined. They were collected aseptically then immediately transported in a cleaning bag to the laboratory and processed within 3 hrs. Clinical and post-mortem examination were done by using the methods described by (Buller, 2004).

Samples for total viable aerobic bacterial counts:

Skin Surfaces: sample from different locations of the skin of all fish was taken by rubbing a sterilized cotton swab over the skin and inoculated into $9 \mathrm{ml}$ of Nutrient broth. 10 serial dilution of the suspended bacterial already inoculated in peptone water was prepared in duplicate and viable aerobic bacterial counts were enumerated using standard plate count agar after incubated at $37^{\circ} \mathrm{C}$ for $48 \mathrm{hrs}$ as described by (Slaby et al., 1981).

Intestines and Gills: samples from the intestines and gills were taken out, blended and mixed completely in a mortar. It was aseptically transferred to a sample bottle containing $9 \mathrm{ml}$ of $0.1 \mathrm{ml}$ sterile peptone water. The bottle was closed and shaken strongly for 10 minutes and allowed to stand for 20 minutes, after which a 10 fold of serial dilution was carried out in duplicates and viable aerobic bacterial counts were counted in standard plate count agar after incubation at $37^{\circ} \mathrm{C}$ for $48 \mathrm{hrs}$. as recommended by (Slaby et al., 1981).

\section{Samples for bacterial isolation and identification:}

Samples were collected from gills, intestine and skin from fishes and cultured on general and specific media; brain heart agar, tryptic soy agar and tryptic soy broth (Difco) added to it $1.5 \%(\mathrm{w} / \mathrm{v}) \mathrm{NaCl}$, aeromonas agar base medium supplemented 
with ampicillin, pseudomonas agar base medium supplemented $2 \% \mathrm{NaCl}$ and azide blood agar supplemented with $2 \% \mathrm{NaCl}$ and S.S agar medium and all media were incubated at $22^{\circ} \mathrm{C}$ for 48 hours. Identification of Listeria monocytogenes was carried out according the outlines recommended by Mc Clain et al. (1998). Enterococcus spp. were isolated by plating on $\mathrm{KF}$ Agar and incubated at $37^{\circ} \mathrm{C}$ for 48 hours. Enterobacteriaceae species were isolated by plating on Hecktoen Agar (Merck, Darmstadt, Germany) and incubated at $37^{\circ} \mathrm{C}$ for 48 hours. Colonies were subjected to Gram Stain and biochemical tests (API 20E, BioMérieux, France), Salmonella spp. was investigated by pre-enrichment in Buffered Peptone Water (Biolife, Milano, Italy), incubated at $37^{\circ} \mathrm{C}$ for 18 hours, and enrichment in Selenite Cystin Broth and Rappaport and Vassiliadiss Broth (Merck, Darmstadt, Germany), both incubated at $37^{\circ} \mathrm{C}$ for 24 hours. Selenite Cystine and Rappaport \&Vassiliadis cultures were streaked on to Rambach agar (Merck, Darmstadt, Germany) and Hecktoen agar (Merck, Darmstadt, Germany) and incubated at $37^{\circ} \mathrm{C}$ for 48 hours. Colonies suspected of being Salmonella spp. were transferred to Lysine Iron Agar and Triple Sugar Iron Agar (Merck, Darmstadt, Germany) and incubated at $37^{\circ} \mathrm{C}$ for 48 hours (FDA, 2001; HOLT, 1994 and Macfiddan, 2000). Staphylococcus spp. were isolated by plating on Baird-Parker Agar (Biolife, Milano, Italy) and incubated at $37^{\circ} \mathrm{C}$ for 48 hours. The colonies were subjected to Gram stain and biochemical tests (API Staphy, BioMérieux, France) (FDA, 2001; HOLT, 1994 and MAC FADDIN, 1980).

Identification of the isolates: pure cultures of the isolates were identified biochemically following the criteria proposed by those described by Garrity, (2001). Confirmation of each strain was reached by using the analytical profile index of the API20-E system (Buller, 2004). Complete identification was done by using VITEK 2 instrument at Biological and chemical war management, Ministry of Military, Egypt. Statistical analysis: data are presented as means \pm standard deviations, according to Statistical Package for Social Science (SPSS) Ver. 14.

Bioaccumulation Factor (BAF): bioaccumulation factor; a major concern for environmental contamination is the extent to which pollutants concentrate from water into aquatic organisms such as fish. The extent of such concentration, termed the bioaccumulation factor (BAF), is given by the ratio of the pollutant concentration in fish to that in water (Chiou, 2002). The BAF for muscle was calculated as follows:

Mean concentration in wet fish muscle $\mathrm{mg} / \mathrm{kg}$ $\mathrm{BAF}=-$

Mean concentration of water $\mathrm{mg} / \mathrm{l}$

Ecological characteristics of fish samples:

\begin{tabular}{|l|l|l|l|l|l|}
\hline $\begin{array}{l}\text { Common } \\
\text { name }\end{array}$ & $\begin{array}{l}\text { English } \\
\text { name }\end{array}$ & $\begin{array}{l}\text { Scientific } \\
\text { name }\end{array}$ & Habitat* & $\begin{array}{l}\text { Feeding* } \\
\text { mode }\end{array}$ & $\begin{array}{l}\text { Food* } \\
\text { source }\end{array}$ \\
\hline Bolti & $\begin{array}{l}\text { Tilapia } \\
\text { fish }\end{array}$ & $\begin{array}{l}\text { Oreochromis } \\
\text { niloticus }\end{array}$ & Benthopelagic & Herbivorous & $\begin{array}{l}\text { Mainly } \\
\text { algae }\end{array}$ \\
\hline
\end{tabular}

* According to Dsikowitzky et al. (2013).

\section{RESULTS AND DISCUSSION}

Results from clinical and post-mortem examination revealed that; symptoms detected in the naturally diseased fish included an increase in mucus secretion, exophthalmia and some fish showed hemorrhages in the eye, and large irregular hemorrhagic areas in many parts of the body, at the base of fins, on the gill cover, at 
the anal region, anal fin. There were abdominal distensions observed. The quantity of mineral nutrients in diet should be balanced to promote optimum response in human metabolism. Heavy metals are persistent contaminants in the environment causing serious illness in fish, animals and human. Regionally, industrial and agricultural runoffs are considered the primary source of metal poisoning for fish and other aquatic animals in Egypt (Badr et al., 2014). The results of the investigation have been summarized in Tables (1-9) and Figures (2-6). The mean values of heavy metals in water and fish tissues are presented in Tables 1,2, 3 and 4 respectively. While the calculated bio-accumulation factors (BAF) for the various heavy metals are also inserted in Table (5).

Environmental pollution is a worldwide problem; heavy metals belonging to the most important pollutants, the progress of industries has led to increased emission of pollutants into ecosystems. The mean concentrations and associated standard deviations of HMs in water were presented in Tables $1 \& 2$, according to the analysis results, the following findings were obtained for the concentration of the metals: $0.63 \pm 0.002$ for $\mathrm{Al}, 0.16 \pm 0.008$ for $\mathrm{Cu}, 0.60 \pm 0.002$ for $\mathrm{Fe}, 0.38 \pm 0.001$ for $\mathrm{Mn}$ and $0.47 \pm 0.007$ for $\mathrm{Zn} \mathrm{mg} / \mathrm{l}$ respectively, meanwhile $0.001 \pm 0.00$ for $\mathrm{Cr}, 0.003 \pm 0.0004$ for $\mathrm{Co}, 0.0024 \pm 0.0001$ for $\mathrm{Ni}, 0.012 \pm 0.0002$ for $\mathrm{Pb}$ and $0.01 \pm 0.0005$ for $\mathrm{Cd}$ were found. Heavy metal concentrations in El-Salam Canal water were decreased in the sequence of $\mathrm{Al}>\mathrm{Fe}>\mathrm{Zn}>\mathrm{Mn}>\mathrm{Cu}>\mathrm{Cd}>\mathrm{Pb}>\mathrm{Co}>\mathrm{Ni}>\mathrm{Cr}$. Results for levels in water were compared with international water quality guidelines. The levels of $\mathrm{Al}, \mathrm{Cu}, \mathrm{Fe}, \mathrm{Mn}$, $\mathrm{Zn}, \mathrm{Co}, \mathrm{Cr}$ and $\mathrm{Ni}$ recorded in El-Salam Canal area in this investigation were higher than maximum acceptable limits recommended by Canadian water quality guidelines for the protection of aquatic life (CCME, 2001) but lower than the maximum acceptable limits in livestock drinking water recommended by WHO, (2008) and US EPA, (2011) for irrigation (Table1) respectively. However, the levels of $\mathrm{Pb}(0.012)$ and Cd (0.01) exceeded these limits. Certainly, extending El-Salam Canal through the semi-arid desert of north Sinai is an attraction for human \& animal activities and fisheries uses.

Table 1: Mean concentration $(\mathrm{mg} / \mathrm{l})$ of heavy metals in water samples from the study area.

\begin{tabular}{|c|c|c|c|c|c|}
\hline Element & Al & Cu & Fe & Mn & Zn \\
\hline wamples & & & & & \\
\hline WHO (2008) & $0.63 \pm 0.002$ & $0.16 \pm 0.008$ & $0.60 \pm 0.002$ & $0.38 \pm 0.001$ & $0.47 \pm .007$ \\
\hline US EPA (2011) & - & 2 & 0.3 & 0.2 & 5 \\
\hline CCME(2001) & 0.087 & 1.3 & 0.3 & 0.05 & 5 \\
\hline
\end{tabular}

Table 2: Mean concentration $(\mathrm{mg} / \mathrm{l})$ of heavy metals in water samples from the study area.

\begin{tabular}{|c|c|c|c|c|c|}
\hline Element & Cr & Co & Ni & Pb & Cd \\
Samples & & & & & \\
\hline water & $0.001 \pm 0.00$ & $0.003 \pm 0.0004$ & $0.0024 \pm .0001$ & $.012 \pm .0002$ & $.01 \pm .0005$ \\
\hline WHO (2008) & 0.05 & 0.005 & 0.3 & 0.003 & 0.003 \\
\hline US EPA (2011) & 0.1 & 0.1 & 0.3 & 0.055 & 0.005 \\
\hline CCME (2001) & 0.05 & - & 0.02 & 0.03 & - \\
\hline
\end{tabular}

World Health Organization (WHO, 2008), US Environmental Protection Agency (USEPA, 2011) and Canadian water quality guidelines for the protection of aquatic life (CCME, 2001).

Therefore, its water quality for different proposes is of much concern, and justifies including bacteriological analyses in the present study. Our results are agree 
with Agrama and Amer, (2012) who concluded that chemical analysis for heavy metals and the water quality index of El-Salam Canal water indicated that concentrations are within the permissible levels for irrigation and livestock but is not suitable for fisheries water. While Hafez et al. (2008) remarkable that heavy metal concentrations limit in their studying area are not acceptable for animal drinking or irrigation purposes. The quality of El-Salam Canal water should be addressed to help monitoring and mitigating the negative impacts of the reused drainage water of the canal on the surrounding environment of north Sinai (Othman et al., 2012). The later author found that $\mathrm{Cu}, \mathrm{Zn}$ concentrations are within the permissible levels for irrigation and drinking water, while $\mathrm{Cd}$ and $\mathrm{Fe}$ concentrations exceeded the permissible levels for both irrigation and drinking livestock at El-Salam canal water.

Moreover, the concentrations of $\mathrm{Al}, \mathrm{Fe}, \mathrm{Mn}, \mathrm{Ni}$ and $\mathrm{Pb}$ were above the permissible limits recommended by EOSQS (1993), and WHO (2008) referring to bad condition of the aquatic ecosystems. In many developed countries, the limits of heavy metals concentrations in fish have been set to safeguard public health. Egypt, for example, has set maximum limits of contamination for heavy metals based on permissible limits recommended by EOSQS, (1993). So this study is focused on determination of selected heavy metals concentrations in the selected tissues of tilapia fish (gills and muscles). In this study, the heavy metal permissible levels in fish tissues were also compared with others such as FAO (1983), EOSQS (1993) and FDA, (2001) (Tables 3\&4). In aquatic ecosystem, heavy metals are considered as the most important pollutants, since they are present throughout the ecosystem and are detectable in critical amounts. Several studies indicated that metal bioaccumulation in fish tissues depend on a number of factors such as food habits and foraging behavior of the fish; trophic status, source of a particular metal, distance of the organism from the contamination source and the presence of other ions in the environment; food availability; bio-magnification and/or bio-diminishing of a particular metal; metal detoxifying proteins in the body of the fish; temperature, transport of the metals across the membrane and the metabolic rate of the animal; species, age, size of fish and exposure time (Ogbeibu and Ezeunara, 2002 and Desta et al., 2012).

Table 3: Mean concentration $(\mathrm{mg} / \mathrm{kg}$ wet weight $\pm \mathrm{SD})$ of heavy metals in different tissues of Nile tilapia (Oreochromis niloticus).

\begin{tabular}{|c|c|c|c|c|c|}
\hline $\begin{array}{l}\text { Element } \\
\text { Samples }\end{array}$ & Al & $\mathrm{Cu}$ & $\mathbf{F e}$ & Mn & Zn \\
\hline Fish Gill & $193 \pm 72.01$ & $5.45 \pm 3.581$ & $406.3 \pm 66.68$ & $9.429 \pm 3.415$ & $22.4 \pm 10.11$ \\
\hline Fish muscle & $93.22 \pm 47.41$ & $3.32 \pm 3.68$ & $189 \pm 9.875$ & $11.79 \pm 17.03$ & $18.28 \pm 4.59$ \\
\hline FAO(1983) & 30 & 3 & 100 & $2.0-9.0$ & $10-75$ \\
\hline EOSQS (1993) & 50 & 20 & 30 & 10 & 40 \\
\hline FDA (2001) & --- & 0.1 & 100 & 100 & 75 \\
\hline
\end{tabular}

FAO (Food and Agricultural Organization), (1983) -FDA (Food and Drug Agency), (1993) \& EOSQS (Egyptian Organization for Standaridization Quality and Control) (2001).

Table 4: Mean concentration $(\mathrm{mg} / \mathrm{kg}$ wet weight $\pm \mathrm{SD}$ ) of heavy metals in different tissues of Nile tilapia (Oreochromis niloticus).

\begin{tabular}{|c|c|c|c|c|c|}
\hline Element & Cr & Co & Ni & Pb & Cd \\
\hline Samples & & & & & \\
\hline Fish Gill & $4.22 \pm 0.39$ & $0.19 \pm 0.32$ & $2.501 \pm 1.093$ & $3.618 \pm 1.09$ & $0.56 \pm 0.22$ \\
\hline Fish muscle & $1.47 \pm 1.014$ & $0.183 \pm 0.3$ & $1.588 \pm 0.285$ & $1.138 \pm 0.56$ & $0.39 \pm 0.20$ \\
\hline FAO (1983) & 0.15 & 0.1 & 0.6 & 0.2 & 2.0 \\
\hline EOSQS (1993) & 20 & 10 & 10 & 2 & 0.5 \\
\hline FDA (2001) & 0.15 & --- & 0.5 & 0.2 & 2.0 \\
\hline
\end{tabular}


FAO (Food and Agricultural organization), (1983)-FDA (Food and Drug Agency), (2001) \& EOSQS (Egyptian Organization for Standaridization Quality and Control)

The same heavy metals ( $\mathrm{Al}, \mathrm{Cu}, \mathrm{Fe}, \mathrm{Mn}, \mathrm{Zn}, \mathrm{Cr}, \mathrm{Co}, \mathrm{Ni}, \mathrm{Pb}$ and $\mathrm{Cd}$ ) were analyzed and the levels of their concentration were measured in fish samples (gills and muscle) from El-Salam Canal area using ICP-MS. The results of the analysis are presented in Tables $3 \& 4$ and further illustrated in Figure 2. In our study we found that accumulation of each heavy metal varied between the fish muscle and gills. Data of HMs concentration showed that HMs were accumulated in the gills of Oreochromis niloticus in the order of $\mathrm{Fe}(406.3)>\mathrm{Al}(193)>\mathrm{Zn}(22.4)>\mathrm{Mn}$ (9.43) > $\mathrm{Cu}$ (5.45) >Cr (4.22) > Pb (3.618) > Ni (2.50) >Cd (0.56) > Co(0.19) ppm respectively, meanwhile these concentration were accumulated in the muscle samples in the order of $\mathrm{Fe}(189)>\mathrm{Al}(93.22)>\mathrm{Zn}(18.28)>\mathrm{Mn}(11.79)>\mathrm{Cu}(3.32)>\mathrm{Ni}$ $(1.58)>\mathrm{Cr}(1.47)>\mathrm{Pb}(1.038)>\mathrm{Cd}(0.39)>\mathrm{Co}(0.183)$ ppm respectively. The present results are good agree with the finding of El-Deek et al. (1994) and Authman et al. (2013) who mentioned that fish muscle tissue is generally low in trace metal content.
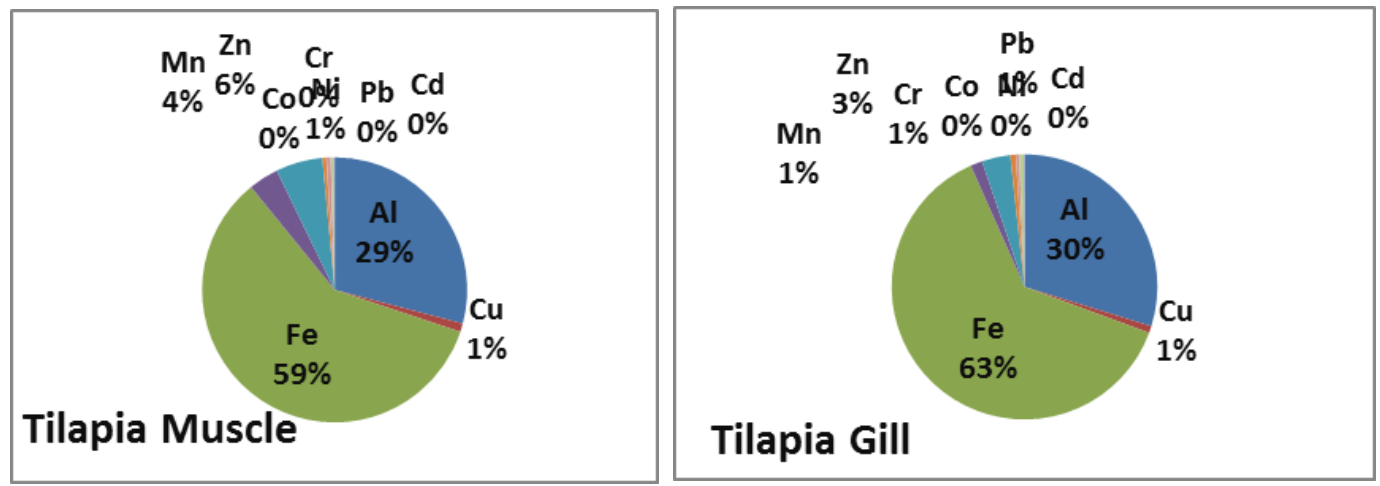

Fig. 2: Content (\%) of the studied HMs in muscle and gill of Oreochromis niloticus

Trace elements in fish tissues were always higher than water that confirmed with Abumourad et al. (2014) and Riani, (2015) and that may be due to the variety of occurrences on fish body and other aquatic biota, including the regular diffusion, biomagnifications, and bioconcentration. The highest concentrations of aluminum, iron, copper and zinc were detected in gill samples, while the minimum values of the same elements were recorded in muscle samples (Table 3). Aluminum has been shown to have deleterious effects on the central nervous, skeletal, and hematopoietic systems of humans. It is worth mentioned that its accumulation in brain altered amino acid neurotransmitters, so it has been suggested to be an associated phenomenon in various neurological disorders as dementia, senile dementia, and Alzheimer disease (Donia, 2015). Comparing our results with the previously reported metals data in fish tissues, it can be noticed that $\mathrm{Al}$ levels were higher than those reported by Authman et al. (2013) who recorded that aluminum concentrations were found to be in the ranges of 4.046 and 9.886, 4.042-9.854 and 8.069-14.204 mg/kg dry wt. for skin, muscles and kidney, respectively. Comparing our results with the permissible limits (Table 3) recommended by FAO (1983), EOSQS (1993) and FDA, (2001), levels of Al in muscles and gills samples are higher than the permissible limits (Table 3). Fe is an abundant and important element, unsurpassed by any other heavy metals in the earth's crust (Badr et al., 2014). It is worth mentioned that Fe levels are higher than the permissible limits recommended by FAO (1983), EOSQS (1993) and FDA, (2001) (Table 3). The increase of Fe accumulation in fish in all examined tissues was higher than the other metals possibly due to the increase of total dissolved $\mathrm{Fe}$ in the 
canal and consequently increases the free metal Fe concentration and there by lead to an increase in metal uptake by different organs. Regarding to copper, the highest concentration $(5.45 \mathrm{mg} / \mathrm{kg}$ ) was recorded in gill samples. Copper is an essential metal which is important for the normal metabolism of fish, and non-essential metals may accumulate in their organs. Moreover, highest concentration of manganese was detected in muscle samples, while the minimum value was recorded in gill samples. Our results showed that the $\mathrm{Mn}$ is highly accumulated in muscles than gills, regarding to manganese concentration in fish samples was $9.429 \pm 3.415 \mathrm{mg} / \mathrm{kg}$ in gill samples and $11.79 \pm 17.03 \mathrm{mg} / \mathrm{kg}$ in muscle samples. Mn concentration was high in muscles samples than gill samples than, these results are disagree with Badr et al. (2014), Osman and Kloas, (2010) who demonstrated that Mn was highly concentrated in the gills of fish from early six sites along the whole River Nile. Manganese is a very common compound that can be found everywhere on earth. It is one out of three toxic essential trace elements, which means that it is not only necessary for humans to survive, but it is also toxic when too high concentrations are present in a human body (Donia, 2015). It is obvious that Mn levels are lower than that recommended by FAO (1983), EOSQS (1993) and FDA, (2001) except fish muscles samples were higher than the permissible limits recommended by EOSQS (1993). Concerning zinc, it is constituent of all cells and is an essential trace element for fishes, it acts as a co-factor for number of enzymes and it is involved in well over one hundred different reactions in the body. It is known that toxicity of zinc is close to toxicity of lead (Kenzhin, 2014). The concentration of zinc in fish organs was $22.4 \mathrm{mg} / \mathrm{kg}$ in gill samples and $18.28 \mathrm{mg} / \mathrm{kg}$ in the muscle samples. Zn concentrations were within permissible limits recommended by FAO (1983), EOSQS (1993) and FDA, (2001). In this study, it is obvious that concentrations were 0.001 for $\mathrm{Cr}, 0.003$ for $\mathrm{Co}, 0.0024$ for $\mathrm{Ni}, 0.012$ for $\mathrm{Pb}$ and 0.01 for $\mathrm{Cd}$. For the gills samples, it may be due to the fact that freshwater fish's gills might be expected to be the primary route for the uptake of water borne pollutants. Essential metals include $\mathrm{Fe}, \mathrm{Cu}, \mathrm{Zn}$ and manganese $(\mathrm{Mn})$, whereas nonessential metals are $\mathrm{Hg}, \mathrm{Pb}$, nickel (Ni) and $\mathrm{Cd}$ (Hashim et al., 2014) Chromium (Cr) is a naturally occurring element found in rocks, animals, plants, and soil, predominantly in its insoluble trivalent form [Cr(III)]. Unfortunately, excessive industrialization and other anthropogenic activities have led to the global occurrence of soluble $\mathrm{Cr}$ (VI) in concentrations above permissible levels.

Regarding to the Bioaccumulation Factor, Table (5) shows it (BAF) for different heavy metals (HMs) from water to Tilapia fish were as follows: 20.75 for $\mathrm{Cu}, 31.02$ for $\mathrm{Mn}, 38.89$ for $\mathrm{Zn}, 39$ for $\mathrm{Cd}, 61$ for $\mathrm{Co}, 94.83$ for $\mathrm{Pb}, 147.96$ for $\mathrm{Al}$, 315 for $\mathrm{Fe}, 661.66$ for $\mathrm{Ni}$ and 1470 for $\mathrm{Cr}$ were found. The result indicating $\mathrm{Cr}$ with a maximum $\mathrm{BAF}$ followed by $\mathrm{Ni}, \mathrm{Fe}, \mathrm{Al}, \mathrm{Pb}, \mathrm{Co}, \mathrm{Cd}, \mathrm{Zn}, \mathrm{Mn}$ and $\mathrm{Cu}$. BAF for $\mathrm{HMs}$ from water to Tilapia fish decreased in the sequence of $\mathrm{Cr}>\mathrm{Ni}>\mathrm{Fe}>\mathrm{Al}>\mathrm{Pb}>$ $\mathrm{Co}>\mathrm{Cd}>\mathrm{Zn}>\mathrm{Mn}>\mathrm{Cu}>$. This results were emphasizes on a large amounts of domestic and agriculture waste water disposal directly or indirectly in the Canal without any treatments.

Table 5: Bioaccumulation Factor (BAF) for different heavy metals from water to fish.

\begin{tabular}{|c|c|c|c|c|}
\hline $\mathbf{A l}$ & $\mathbf{C u}$ & $\mathbf{F e}$ & $\mathbf{M n}$ & $\mathbf{Z n}$ \\
\hline 147.96 & 20.75 & 315 & 31.02 & 38.89 \\
\hline $\mathbf{C r}$ & $\mathbf{C o}$ & $\mathbf{N i}$ & $\mathbf{P b}$ & $\mathbf{C d}$ \\
\hline 1470 & 61 & 661.66 & 94.83 & 39 \\
\hline
\end{tabular}


Concerning the bacteriological analysis for water, bacterial counts are shown in Table (6) \& Figure (3). The number of the distribution and seasonal variations of the total aerobic bacteria at $22^{\circ} \mathrm{C}$ ranged between $15 \times 10^{6}-940 \times 10^{6} \mathrm{CFU} \mathrm{ml}^{-1}$, while the bacteria developing at $37^{\circ} \mathrm{C}$ varied from $19 \times 10^{6}-870 \times 10^{6} \mathrm{CFU} \mathrm{ml}{ }^{-1}$. The maximum bacterial counts were detected during spring 2016 reflecting the effect of high content of organic matter due to flourishing of phytoplankton which increased active multiplication of the bacteria. This agrees with explanation for increase bacterial counts in spring after year (Sabae et al., 2008) but the numbers that we obtained at the same site of El Salam Canal are more than those written in previous research, and this may be due to increased pollution and climate change.

Table 6: Total viable bacterial counts $\times 10^{6} \mathrm{CFU} \mathrm{ml}^{-1}$, water at $22^{\circ} \mathrm{C}$ and $37^{\circ} \mathrm{C}$

\begin{tabular}{|c|c|c|c|c|c|c|c|c|c|}
\hline \multicolumn{2}{|c|}{ Spring } & \multicolumn{2}{c|}{ Summer } & \multicolumn{2}{c|}{ Autumn } & \multicolumn{2}{c|}{ Winter } & \multicolumn{2}{c|}{ Spring } \\
\hline $22^{\circ \mathrm{C}}$ & $37^{\circ} \mathrm{C}$ & $22^{\circ}$ & $37^{\circ} \mathrm{C}$ & $22^{\circ}$ & $37^{\circ} \mathrm{C}$ & $22^{\circ}$ & $37^{\circ} \mathrm{C}$ & $22^{{ }^{\circ} \mathrm{C}}$ & $37^{\circ}$ \\
\hline 39 & 45 & 32 & 36 & 15 & 19 & 350 & 250 & 940 & 870 \\
\hline
\end{tabular}

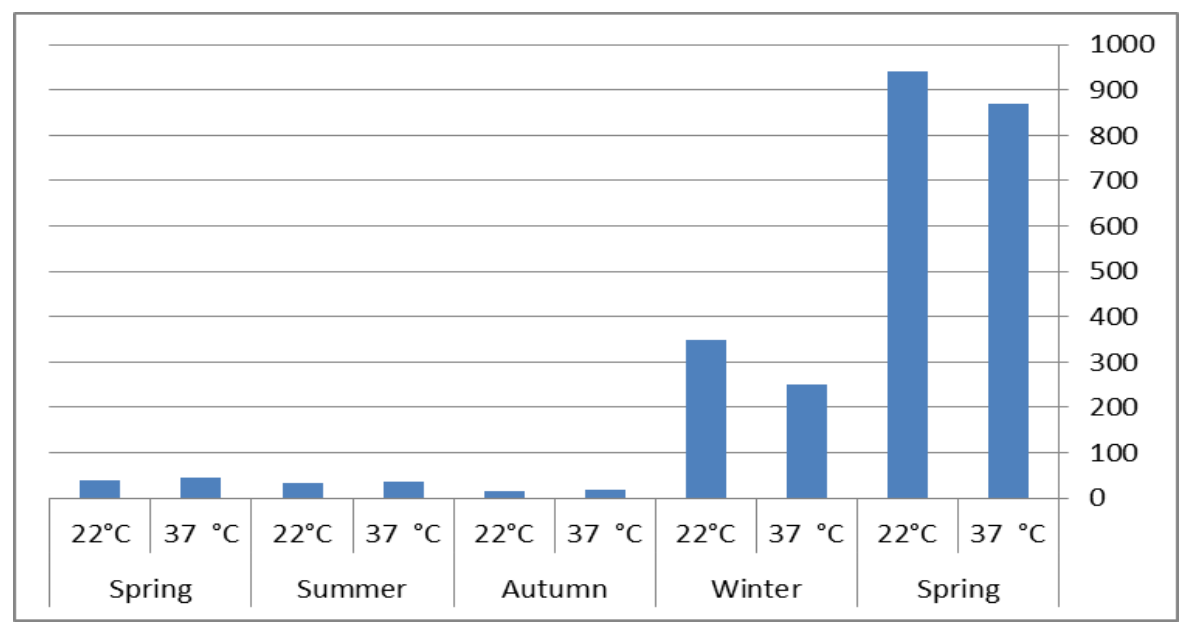

Fig. 3: Total viable bacterial counts $\times 106 \mathrm{CFU} \mathrm{ml}-1$ water at $22^{\circ} \mathrm{C}$ and $37^{\circ} \mathrm{C}$

The most probable numbers (MPN) of indicator bacteria are recorded in Table 7 and Figure (4). Their numbers were in the ranges of $11 \times 10^{2}-90 \times 10^{3}, 5 \times 10^{2}-32$ $\times 10^{3}$ and $3 \times 10^{2}-15 \times 10^{3}$ MPN/ $100 \mathrm{ml}$ water for total coliforms (TC), fecal coliforms (FC) and fecal streptococci (FS), respectively. Generally the result of the this study showed increased in the indicator bacteria as compared with the previous results reported by Othman et al. (2008) and yehia and Sabae, (2011) we also realized that the environmental conditions as solar radiation, turbidity, temperature and salinity, they are affect the presence of indicator bacteria in El-Salam Canal. The minimum counts of the indicator bacteria were recorded in the warmer seasons which due to increasing of solar radiation and high temperature (Kocacy, 1989 and El-Shenawy, 2005). Some officials present FC and FS data as a ratio in an attempt to indicate the origin of bacterial pollution. FC/FS ratio of 4 or greater has been said to indicate a human source. The corresponding ratio for domestic animals is on average of 0.1- 0.6 and for wild animals less the ratio than 0.1. As this ratio has been applied to surface and ground water samples, these numbers hold true only for recent fecal contamination (US EPA, 2001) In the present study FC/FS ratios were in the ranges of 1.4, 3.6, 0.38, 2 and 2.1 for the studied seasons, respectively, which indicated mixed origin of fecal pollution and are agree with those previously reported by Sabae and Abdel- Rahman, (2008). 
Table 7: The most probable number of total coliforms (TC), fecal coliforms (FC) and fecal streptococci (FS) $\times 10 \mathrm{MPN} / 100 \mathrm{ml}$ water

\begin{tabular}{|c|c|c|c|c|c|c|c|c|c|c|c|c|c|c|}
\hline \multicolumn{3}{|c|}{ Spring } & \multicolumn{3}{|c|}{ Summer } & \multicolumn{3}{|c|}{ Autumn } & \multicolumn{3}{|c|}{ Winter } & \multicolumn{2}{|c|}{ Spring } & \\
\hline TC & FC & FS & TC & FC & FS & TC & FC & FS & TC & $\mathrm{FC}$ & FS & $\mathrm{TC}$ & $\mathrm{FC}$ & FS \\
\hline 11 & 13 & 9 & 15 & 11 & 3 & 11 & 5 & 13 & 90 & 24 & 11 & 48 & 32 & 15 \\
\hline
\end{tabular}

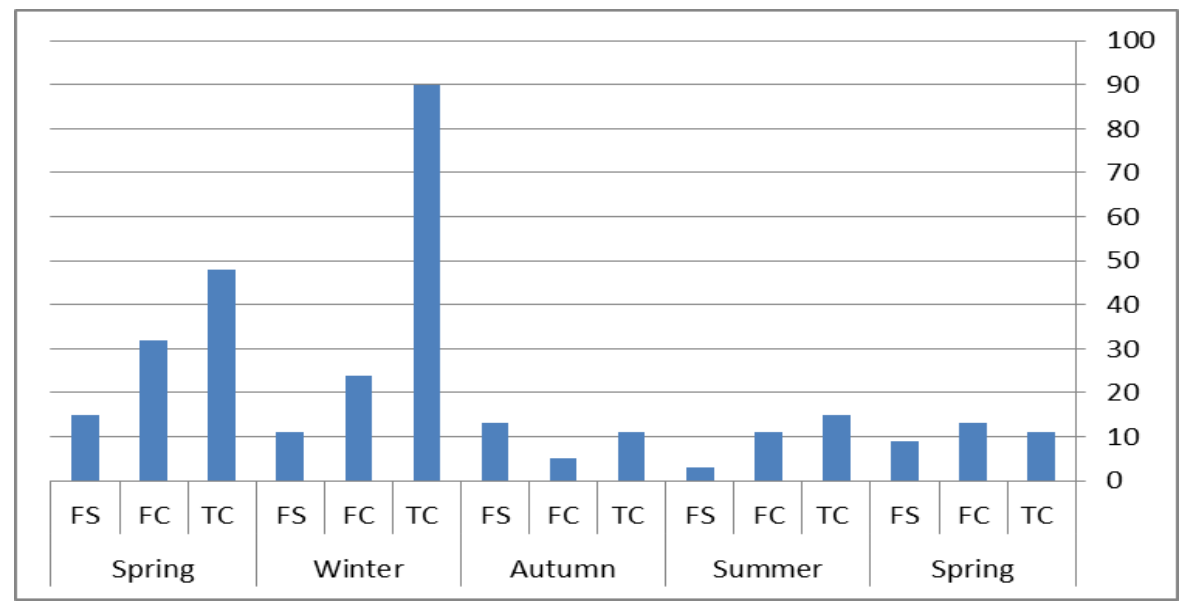

Fig. 4: The most probable number of total coliforms (TC), fecal coliforms (FC) and fecal streptococci $(\mathrm{FS}) \times 10 \mathrm{MPN} / 100 \mathrm{ml}$ water

During the present study, the counts of pathogenic bacteria Pseudomonas aeruginosa (Table 8 and Figure 5) ranged in El-Salam Canal waters from 80 to 200 MPN/100 ml, while the numbers of Salmonella-Shigella varied from 0 to $30 \mathrm{CFU} \mathrm{ml}$ and E.coli colony number range from 0 to 10 this result come is agree with yehia and Sabae, (2011). This might be due to the effects of different environmental factors like amount of suspended matter in addition to the amount of wastewater discharge by the drains into the canal.

Table 8: The numbers of pathogenic bacteria (Pseudomonas aeruginosa MPN/100ml and SalmonellaShigella CFU ml water and E. coli colony )

\begin{tabular}{|c|c|c|c|c|c|c|c|c|c|c|c|c|c|c|}
\hline \multicolumn{3}{|c|}{ Spring } & \multicolumn{3}{|c|}{ Summer } & \multicolumn{3}{|c|}{ Autumn } & \multicolumn{3}{|c|}{ Winter } & \multicolumn{2}{|c|}{ Spring } & \\
\hline Ps. & s. s & E. coli & Ps. & S.s & E. coli & Ps. & S.S & E.coli & Ps. & S.S & E. coli & Ps. & S.S & E-coli \\
\hline 110 & 0 & 0 & 90 & 10 & 3 & 100 & 20 & 5 & 200 & 30 & 10 & 80 & 0 & 0 \\
\hline
\end{tabular}

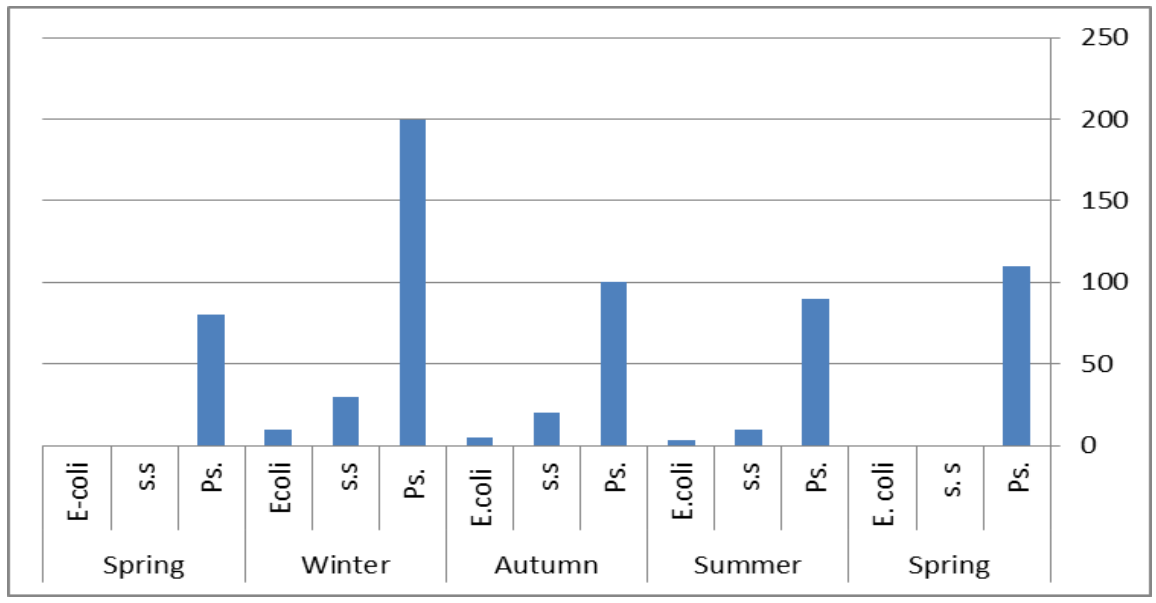

Fig. 5: The numbers of pathogenic bacteria (Pseudomonas aeruginosa MPN/100 ml and SalmonellaShigella $\mathrm{CFU} \mathrm{ml}$ water and E.coli colony). 
Concerning the results and discussion of bacteriological analysis, for fish a range of total viable count of the three sites analyzed revealed $38.75 \times 10^{8} \mathrm{cfug}^{-1}$ from the skin, $20 \times 10^{8} \mathrm{cfug}^{-1}$ from the intestine $44.5 \times 10^{7} \mathrm{cfug}^{-1} 1$ and from the gills, this come agree with (Shinkafi and Ukwaja, 2010) they confirm that skin is one of the most common segment that contains bacteria. The frequency of occurrence of bacterial isolates is shown in Table (9) and Figure (6):

Table 9: Frequency of occurrence of bacterial isolates

\begin{tabular}{|l|c|c|}
\hline Bacterial isolates & Number of occurrences & $\%$ occurrence \\
\hline Salmonella spp & 8 & $5.6 \%$ \\
\hline Enterobacter cloacae & 9 & $6 \%$ \\
\hline Rhizobium radiobacter & 12 & $8.4 \%$ \\
\hline Ps. fluorescens & 14 & $9.7 \%$ \\
\hline Listeria monocytogenes & 21 & $14.7 \%$ \\
\hline Streptococcus agalactiae & 22 & $15.4 \%$ \\
\hline Streptococcus iniae & 25 & $17.5 \%$ \\
\hline Aeromonas hydrophila & 32 & $22.4 \%$ \\
\hline total & 143 & \\
\hline
\end{tabular}

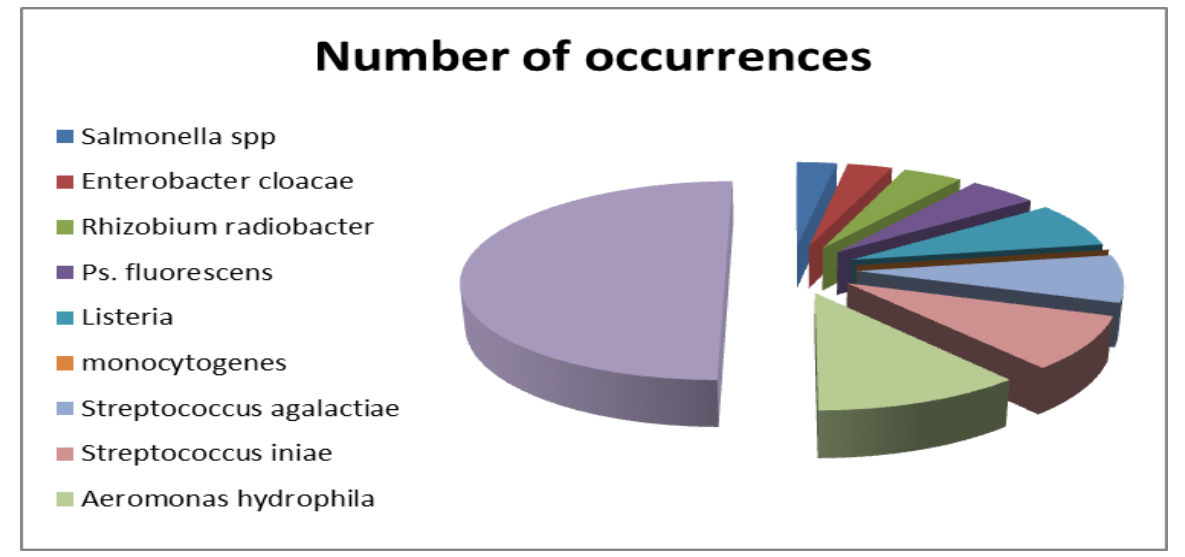

Fig. 6: Frequency of occurrence of bacterial isolates

The results from this research indicate that the bacterial load variations in the three segments of the fishes analyzed the skin, intestine and gills. The bacterial load in all samples was high and may be explained to the high ambient temperature in the river where it was close to optimum for many bacteria. Bacterial load in fish might increase with the increase of water temperature (Fernandes et al, 1997). Choudhury et al, (1989) reported an intestinal bacterial load of Tilapia fish as $5.5 \times 10^{9} \mathrm{cfu} / \mathrm{g}$, this count is less than our results $\left(20 \times 10^{8}\right)$ in this research at similar temperature this may due to increase in pollution during the year. The high bacterial count on the skin may be due to increase contamination by genuinely aquatic species as well as those that contaminate the commodity during handling. The gills had the lowest bacterial population, compared to the intestine and skin. According to Trust, (1975) and Shinkafi \& Ukwaja, (2010) the number of bacteria associated with the gills are actively maintained at a low level, thereby implying that fish probably has a mechanism which enables it to keep the bacteria number low and therefore afford it some degree of protection against bacterial invasion by the gill microflora (Ezeriet al., 2001) Shinkafi and Ukwaja. (2010). Based on the percentage frequency of occurrence of Salmonella spp showed the least frequency of 5.6\% and Enterobacter cloacae 6\%. Presence of Salmonella spp. and Enterobacter cloacae in the fish tissue and in the water suggest pollution this result come with (Burras, 1993) who suggest 
possibly from contamination with animal waste from chicken as observed by Abed El-Aziz and Ehab, (2003). Salmonella spp. has been reported to cause enteritis and systematic disease, Rhizobium radiobacter bacteria isolated by $8.4 \%$ percent, it may be due to legumes are in ingredients for fish feed which may contaminated by Rhizobium radiobacter or the water is contaminated with these bacteria and thus contaminated the fish skin. Ps. Fluorescens is widely distributed in natural sources of water and considered as one of the primary cause of septicemia in both freshwater and marine fish throughout the world and causes severe economic losses and decreases fish farm efficiencies (Olsson et al., 1998) and it isolated by $9.7 \%$. These results came in accordance with those obtained by Atwa, (2007) and Saad El-Deen, (2014). The percentage frequency of occurrence of Listeria monocytogenes $14.7 \%$ these findings is in agreement with other previous studies of Shinkafi and Ukwaja (2010), this may due to two sources of fish contamination which includes; the attack of Listeria from intestinal contents to other fish tissues like muscles, especially when the time from fish death till removing the viscera is more than a few hours (Ertas et al., 2005), cross contamination (fish manipulation, using contaminated equipments and inappropriate transport) (Gudbjornsdottir et al., 2004), it's importance come due to it produces a series of toxins hemolytic, lipolytic, hemorrhagic and pyrogenic which are involved in the disease process, the bacterium can also invade the eye and skin cause conjunctivitis and skin lesions (Bahk, and Marth, 1990). Regarding to Streptococcus agalactiae, a gram-positive bacterium which isolated by $15.4 \%$, that can infect a number of fish species, including freshwater and seawater species, the percent was in accordance with earlier reports of (Baeck et al. 2006; Garcia et al. 2008; Ye et al. 2011; Chen et al. 2012). Tilapia is extremely susceptible to infection by St. agalactiae and is able to cause disease and death in Nile tilapia (Ye et al. 2011; Chen et al. 2012), Streptococcus iniae 17.5\% an important pathogen in aquaculture, which may cause considerable economic losses and infect different species of marine and freshwater fish. Furthermore, it is an emerging zoonotic pathogen as previously reported by Agnew and Barnes (2007) \& Baiano and Barnes (2009). In contrast, Aeromonas hydrophila record high percentage this may due to is related to sudden changes in temperature, dissolved oxygen and inadequate nutrition as pointed out by Conroy, (2014) who indicate that the constant variation of physicochemical parameters is a stress factor that benefits the outbreak of disease caused by opportunistic bacteria. According to Tryfinopoulo et al. (2002) both Pseudomonas spp. and Aeromonas spp. show high capacity to produce exoenzymes as lipases and proteases whose actions are associated to fish product deterioration.

\section{CONCLUSIONS}

According to the uses of El-Salam Canal in fisheries the results of the present study clearly demonstrate that it is contaminated with $\mathrm{Al}, \mathrm{Cu}, \mathrm{Fe}, \mathrm{Mn}$ and $\mathrm{Zn}$ due to the continuous discharge of different pollutants as a result of mixing drainage water with the Nile water. Metal contamination in water followed the order of $\mathrm{Al}>\mathrm{Fe}>\mathrm{Zn}>\mathrm{Mn}>\mathrm{Cu}>\mathrm{Cd}>\mathrm{Pb}>\mathrm{Co}>\mathrm{Ni}>\mathrm{Cr}$. While these concentrations in fish organs followed the order of $\mathrm{Fe}>\mathrm{Al}>\mathrm{Zn}>\mathrm{Mn}>\mathrm{Cu}>$ $\mathrm{Cr}>\mathrm{Pb}>\mathrm{Ni}>\mathrm{Cd}>\mathrm{Co}$. Metal accumulation in Oreochromis niloticus reflects the degree of water pollution. Also, this research sheds considerable light on the bacterial species associated with fresh Tilapia fish and water which they are potentially pathogenic to humans. Hence, adequate measures should be taken in processing the fish before consumption, great efforts and cooperation between different authorities are needed to protect the Canal from pollution and reduce environmental risk. This can be achieved by treatment of the agricultural, industrial, and sewage discharge. Regular evaluation of pollutants in the Canal is 
also very important. Finally, the high levels of bioaccumulation factor of $\mathrm{Cr}, \mathrm{Ni}, \mathrm{Fe}, \mathrm{Al}$ and Mn shows that they were good bioindicator to monitor pollution in this study. The quantities of HMs in fish muscles and gills measured in this study provide baseline information on concentrations and distribution of heavy metals and light on the bacterial species in Oreochromis niloticus from El-Salam Canal, Northern Sinai Egypt. So, our results clearly indicate the urgent need for effective strategies for the treatment of the drainage water resources before mixing with the Nile water, and the water in the area of study used with some restriction for the parameters which not comply with different guidelines. Therefore, further studies are strongly recommended for monitoring environmental pollution in this area.

\section{REFERENCES}

Abd El-Aziz, M. A. and Ehab, I. M. (2003). Risk assessment of using of poultry droppings and poultry viscera as feeds for cultured tilapia and catfish (Clariaslazera), evaluation of their tremendous effects on water, fish, as well as their human health hazards. Proc. Conf. Fish Wealth and Food Security in Arabic and Islamic Countries. Al-Azhar Univ. Oct. 22 - 24, 18pp.

Abdel-Mohsien, H. S. and Mahmoud, M. A. M. (2015). Accumulation of Some Heavy Metals in Oreochromis niloticus from the Nile in Egypt: Potential Hazards to Fish and Consumers. J. Environmental Protection, 6: 1003-1013.

Abisoye, B. F.; Ojo, S. K. S.; Adeyemi, R. S. and Olajuyigbe, O.O. (2011). Bacteriological assessment of some commonly sold fishes in Lagos metropolis market Nigeria. Prime. Journal of Microbiology Research, 1(2):23-26.

Abumourad, I.M.K.; Abbas, W.T.; Authman, M.M.N. and Girgis, S.M. (2014). Environmental Impact of Heavy Metal Pollution on Metallothionein Expression in Tilapia nilotica. Egypt. J. Res. Pharma. Biol. \& Chem. Sci., 5(2): 987- 998.

Agnew, W. and Barnes, A. C. (2007). Streptococcus iniae: An aquatic pathogen of global veterinary significance and challenging candidate for reliable vaccination. Veterinary Microbiologic, 122: 1-15.

Agrama, A. A. and Amer, A. S. (2012). Investigation of El-Salam Canal Water Quality, South El-Qantara Sharq Area. J. Appl. Sci. Res., 8(4): 1927-1935.

Akan, J. C.; Abdulrahman, F. I.; Sopido, O. A. and Akandu, P. I. (2009). Bioaccumulation of some heavy metals of six fresh water fishes caught from Lake Chad in Doron Buhari, Maiduguri, Borno State, Nigeria. J. Appli. Sci. and Sanitation, 4(2): 103-114.

Al-Harbi, A. H. (2003). Faecal coliforms in pond water, sediments and hybrid tilapia Orecochromis niloticus and Oreochromis aureus in Saudi Arabia. Aquacult Res, 34: 517-524.

APHA (American Public health Association), (2005). Standard methods for the examination of water and wastewater, 21 Ed., Washington D.C.

ASTM, (2002). American Society for Testing and Materials "Water and environmental technology". Annual book of ASTM standards, Sec. 11, Vol. 11.01 and 11.02, West Conshohocken, U.S.N.

Atwa, E. J. (2007). "Bacteriological studies on Psudomonas microorganism in wild and cultured Oreochromis niloticus" . J. Egypt. Vet. Med. Asso., 67(2): 29- 42.

Authman, M. M. N.; Abbas, H. H. and Abbas, W.T. (2013). Assessment of metal status in drainage canal water and their bioaccumulation in Oreochromis niloticus fish in relation to human health. Environ Monit Assess, 185:891-907.

Badr, A. M.; Mahana, N. A. and Eissa, A. (2014). Assessment of Heavy Metal Levels in Water and Their Toxicity in Some Tissues of Nile Tilapia 
(Oreochromis niloticus) in River Nile Basin at Greater Cairo, Egypt. Global Veterinaria, 13(4): 432-443,

Baeck G.W.; Kim J. H.; Gomez D. K. and Park, S. C. (2006). Isolation and characterization of Streptococcus sp. from diseased flounder (Paralichthysolivaceus) in Jeju Island. J. Veterinary Science, 7: 53-58.

Bahk, J. and Marth, E. M. (1990). Listeriosis and Listeria monocytogenes in food borne disease. Academic press Inc. New York, pp. 248-257.

Baiano, J. C. F. and Barnes, A. C. (2009). Towards control of Streptococcus iniae. J. Emerging Infectious Diseases, 15: 1891-1896.

Bayomy, M. F. F; Alne-na-ei, A. A.; Gaber, H. S.; Sayed, H. A. and Khairy D.M. (2015). Environmental and physiological impacts of heavy metals on Nile tilapia (Oreochromis niloticus). J. Bioscience and Applied Res., 1 (2): 52-58.

Burras, N. (1993). Microbial Safety of Procedure from Wastewater-Fed Aquaculture. In: Envirmonment and Aquaculture in Developing Countries, Pullin, R.S.V., H. Rosenthal and J.L. MacLean (Eds.). The World Fish Center, Manila, Philippines, pp. 285-295.

Cahill, M. M. (1990): Bacterial flora of fishes: a review. Journal of Microbial Ecology, 19(1):21-41.

Canli, M. and Atli, G. (2003). The relationship between heavy metal $(\mathrm{Cd}, \mathrm{Cr}, \mathrm{Cu}, \mathrm{Fe}$, $\mathrm{Pb}, \mathrm{Zn}$ ) levels and size of six Mediterranean fish species. Environ Pullut., 121: 129-136.

CCME (Canadian water quality guidelines for the protection of aquatic life), (2001). Canadian Water Quality Index 1.0 Technical Report. Canadian Environmental Quality Guidelines, Winnipeg, Manitoba.

Chen M.; Li L.P.; Wang R.; Liang W.W.; Huang Y.; Li J.; Lei A.Y.; Huang, W.Y. and Gan, X. (2012). PCR detection and PFGE genotype analyses of streptococcal clinical isolates from tilapia in China. Veterinary Microbiology, 159: $526-530$

Chiou, C. T. (2002). Bioconcentration of organic contaminants, in Partition and Adsorption of Organic Contaminants in Environmental Systems: Hoboken, N.J., John Wiley \& Sons, Inc., 257pp.

Choudhury, M.B; Munirzzaman, M. and Uddin, M. N. (1989). Study on the intestinal bacterial flora of Tilapia. Oreochromis niloticus. Bangladesh aquaculture 11:65-70

Claucas, I. J. and Ward, A. R. (1996). Post-harvest fisheries development: a guide to handling, preservation, processing and quality. $443 \mathrm{pp}$.

Conroy, G. (2014). Most frequent tilapia diseases in Latin America and the Caribbean. 9th International Aquaculture Forum. World Aquaculture Society

DESTA, M. B.; ASGEDOM, A. G. and GEBREMEDHIN, Y.W. (2012). Health Risk Assessment Of Heavy Metals Bioaccumulation In Water, Sediment And Three Fish Species (Labeobarbus spp, Clarias Gariepinus And Oreochromis niloticus) of Tekeze River Dam, Tigray, Northern Ethiopia. Journal of Atmospheric and Earth Environment, 1(1): 19-29.

Donia, G. R. (2015). Determination of some heavy elements residues in some organs of migratory quail in relation to public health. International Journal of Science and Research (IJSR), 4(10): 2048-2059.

Dsikowitzky, L.; Mengesha, M.; Dadebo E.; Veiga de Carvalho C.E. and Sindern S., (2013). Assessment of heavy metals in water samples and tissues of edible fish species from Awassa and Koka Rift Valley Lakes, Ethiopia. Environ Monit Assess, 185:3117-3131. 
El-Deek, M.; Abbas, M.; Naguib, K. h. and Naguib, M. (1994). Cu, Zn and Pb in Epinephelus spp. in the Red Sea. In Proceedings of the 4th Conference of the Environmental protection is a must (pp. 229-236). Alexandria, Egypt.

ELShafei, H. M. (2015). Some Heavy Metals Concentration in Water, Muscles and Gills of Tilapia Niloticus as Biological Indicator of Manzala Lake Pollution. $J$ Aquac Res Development, 6 (9): 358-363.

El-Shenawy, M. A. (2005). Staphylococcus aureus and fecal indicators in Egyptian coastal waters of Aqaba Gulf and Red Sea. Egypt. J. Aquat. Res., 13(2): 113124.

Emara, M. M.; Farag, R. S.; Dawah, A. A. and Fathi, M. (2015). Assessment of Heavy Metals Concentration in Water and Edible Tissues of Nile Tilapia (Oreochromis niloticus) from two Fish Farms Irrigated with Different Water Sources, Egypt. International Journal of Environment, 4(1): 108-115.

EOSQS (Egyptian Organization for Standaridization Quality and Control) (1993). "Maximum level for heavy metal contaminants in Food." Es. no. 2366.

Ertas, H.B. and Seker, E. (2005). Isolation of Listeria monocytogenes from Fish Intestines and RAPD Analysis. Turk. J. Vet. Anim. Sci., 29: 1007-101.

Ezeri, G. N. O. (2001). Hematological response of clariasgariepinus to bacterial infection and prophylactic treatment with antibiotics, journal of Aquartic Science, 16:22-24.

FAO (Food and Agricultural organization), (1983). Compilation of legal limits for hazardous substances in fish and fishery products. Fisheries circular; 464:5100. FAO, Rome

Farkas, A; Salanki, J. and Varanka, I. (2000). Heavy metal concentrations in fish of Lake Balaton, Lakes and Reservoirs Research and Management, 5: 271-79.

FDA (Food and Drug Agency) (2001). Fish and fisheries products hazards and controls guidance. 3. Silver Spring: Center for Food Safety and Applied Nutrition, US Food and Drug Administration.

Fernandes, C.F.; Flick, G.J.; Sivia J. L. and McCasky, T.A. (1997). Influence of processing schemes on indicative bacteria and quality of fresh aquacultured cat fish filltes. 60: 54-58.

Garcia J. C.; Klesius P.H.; Evans J. J. and Shoemaker C. A. (2008). Non-infectivity of cattle Streptococcus agalactiae in Nile tilapia, Oreochromis niloticus and channel catfish, Ictalurus punctatus. J. Aquaculture, 281: 151-154.

Garrity, G. M. (2001). Bergey's Manual of systemic Bacteriology $2^{\text {nd }}$ Ed. Springer, New York

Gudbjornsdottir, B.; Suihko, M. L.; Gustavsson, P.; Thorkelsson, G.; Salo, S.; Sjöberg, A.M.; Niclasen, O. and Bredholt, S. (2004). The incidence of Listeria monocytogenes in seafood in the Nordic countries. Food Microbiol., 21: 217225.

Hafez, A. M.; Khedr, K.; El-Katib, H.; Gad Alla and El-Manharawy, S. (2008). ElSalam Canal Project, Sinai II. Chemical Water Quality Investigations, Journal of Desalination, 227: 274-285.

Hashim, R.; Song, T. H.; Zuhartini, N. and Yen,T. P. (2014). Determination of Heavy Metal Levels in Fishes from the Lower Reach of the Kelantan River, Kelantan, Malaysia. J. Tropical Life Sciences Research, 25(2): 21-39.

Holt, J. G.; Krieg, N. R.; Sneath, P. H.; Staley, J. T. and William, S. T. (1994). Bergey's Manual of Determinative Bacteriology 9th Ed. William and Wikins Co. Baltimore. London. 79pp. 
Huong, N.T.T.; Thuy, H. L.; Gallardo, W. G. and Thanh, H. N. (2014). Bacterial population in intensive tilapia (Oreochromis niloticus) culture pond sediment in Hai Duong province, Vietnam. Interntional Journal of fisheries and aquaculture, 6: 133-139.

Kenzhin, Z. D. (2014). Comparative Analysis of Heavy Metals (Mn, Zn, Ni, Co, $\mathrm{Cr} 3+, \mathrm{Sr}, \mathrm{Fe}, \mathrm{Pb}, \mathrm{Cd}, \mathrm{Co})$ Accumulation Ability in Fish Species Sander lucioperca L. and Neogobiusmelanostomus P. at the Coastal Sea Waters of The Northern and Central Part of Caspian Sea. American-Eurasian. Journal of Toxicological Sciences, 6 (4): 123-130.

Kocacy, C. (1989). A method for prediction of extent of microbial pollution of seawater and carrying capacity. J. Environ. Manag., 13 (4): 469-475.

Lipp, E. K. and Rose, J. B. (1997). The role of seafood in food borne diseases in the United States of America. Rev. Sci. Tech., 16: 620-640.

Macfaddin, J. F. (2000). Biochemical Tests for Identification of Medical Bacteria.3rd Ed. Lippincott Williams and Wilkins USA.

Moiseenko, T. I.; Gashkina, N. A.; Sharova,Yu. N. and Kudriavtseva, L. P. (2008). Ecotoxicological assessment of water quality and ecosystem health: a case study of the Volga River. J.Ecotoxicology and Environmental Safety, 71: 837850 .

Ogbeibu, A. E. and Ezeunara, P.U. (2002). Ecological impact of brewery effluent on the kpoba river using the fish communities as bio-indicators. Journ. Aquatic Sciences, 17: 35-44.

Olsson, J. C.; Joborn, A.; Westerdahl, A.; Blomberg, L.; Kjelleberg, S. and Conway, P.L. (1998). Survival, Persistence and Proliferation of Vibrio anguillarum in Juvenile turbot, Scophthalmusmaximus (L.), intestine and faeces. Journal of Fish Diseases, 21: 1-9.

Osman, A.G.M. and Kloas, W. (2010). Water quality and heavy metal monitoring in water, sediments and tissues of the African Catfish Clariasgariepinus. J. Environmental Protection, 1: 389-400.

Othman, A. A.; Rabeh, S. A.; Fayez, M.; Monib, M. and Hegazi, N. A. (2012). ElSalam Canal is a potential project reusing the Nile Delta drainage water for Sinai desert agriculture: Microbial and chemical water quality. Journal of Advanced Research, 3: 99-108.

Othman, A. A.; Rabeh, S.A.; Fayez, M.; Monib, M. and Hegazi, N. A. (2008). The water quality of El-Salam Canal, North Sinai, Egypt. J. Egypt. Acad. Soc. Environ. Develop., 9(1): 47-64.

Ravera, R.C.; Beone, G.M.; Dantas, M. and Lodigiani, P. (2003). Trace element concentrations in freshwater mussels and macrophytes as related to those in their environment, Journal of Limnology, 62: 61-70.

Riani, E. (2015). The Effect of Heavy Metals on Tissue Damage in Different Organs of Goldfish Cultivated in Floating Fish Net in Cirata Reservoir, Indonesia. INDIAN JOURNAL OF RESEARCH, 4(2):132-136.

Saad EL -Deen, A. G. (2014). Role of Nigella Sativa in decreasing mortalities in Nile tilapia caused by Pseudomonas septicemia. Assiut. Vet. Med. J. 60(142): 89-94.

Sabae, S. Z. and Abdel-Rahman, S.H. (2008). Bacteria as indicator of sewage pollution and as a trophic level in some selected khores of Lake Nasser, Egypt. J. Egypt Aquat. Res. 34(2): 206-216.

Sabae, S. Z.; Emam, W. M. and Rabeh, S. A. (2008). Microbial characteristics of Wadi El-Raiyan Lakes, Egypt. J. Egypt. Acad. Soc. Environ. Develop, 9(2): 1728. 
Shinkafi, S. A. and Ukwaja, V. C. (2010). Bacteria Associated with Fresh Tilapia Fish (Oreochromis niloticus) Sold at Sokoto Central Market in Sokoto, Nigeria. Nigerian Journal of Basic and Applied Science, 18(2): 217-221.

Slaby, B. M.; Martin, R. E.; Ramsdell, G. E. (1981). Reproducibility of Microbiological counts on frozen Cod: A collaborative study. J. Food Sci. 46(3): 716-719.

Snieszko, S. F. (1975). History and present status of fish diseases. J Wild Dis, 11: 446-459.

Svobodova, Z.; Celechovska, O.; Kolara, J.; Randak, T. and Zlabek, V. (2004). Assessment of metal contamination in the upper reaches of the Ticha Orlice River, Czech. J. Anim. Sci., 49: 458-64.

Trust, T. J. (1975). Bacteria associated with the gill of Salmond fishes in fresh water. Journal of applied bacterialogy, 88(3): 225-233.

Tryfinopoulo, P.; Tsakalidou, E. and Nuchas, G. J. E. (2002): haracterization of Pseudomonas spp. associated with spoilage of gilt-heat bream stored under various conditions. Applied and Environmental Microbiology, 68(1): 65-72.

US EPA (U.S. Environmental Protection Agency), (2001). Protocol for Developing Pathogen. TMDLS, EPA 841-R-002.

US EPA (U.S. Environmental Protection Agency), (2011). Drinking water quality, Heavy metals, Maximum admissible limit. 3: 105-121.

WHO (World Health Organization), (2008). Guidelines for drinking water quality, Geneva.

Ye, X.; Li, J.; Lu, M.X.; Deng, G.C.; Jiang, X.Y.; Tian, Y.Y.; Quan, Y.C. and Jian Q. (2011). Identification and molecular typing of Streptococcus agalactiae isolated from pond-cultured tilapia in China. Fisheries Science, 77: 623-632.

Yehia, H. M., and Sabae, S. Z. (2011). Microbial Pollution of Water in El-Salam Canal, Egypt, American-Eurasian J. Agric. \& Environ. Sci., 11 (2): 305-309.

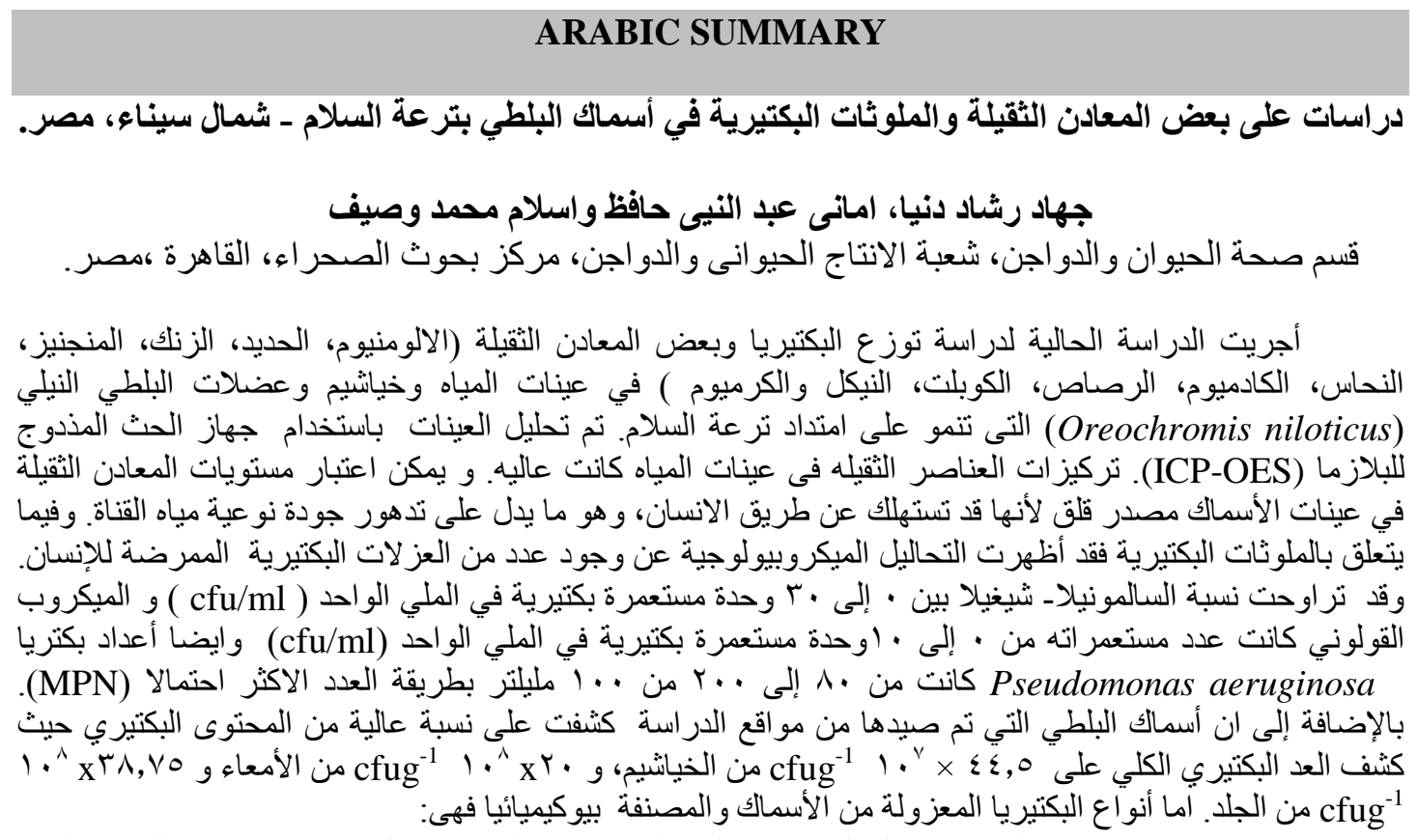

Salmonella spp., Enterobacter cloacae, Rhizobium radiobacte., Fluorescens spp., Listeria .monocytogenes, Streptococcus agalactiae, Streptococcus iniae and Aeromonas hydrophila. لذلك فإن مزيد من الاجر اءات يجب ان تتخذ للحد من مصادر تلوث نرعة السلام. 